\title{
EFFECT OF VITAMIN D SUPPLEMENTATION ON MUSCLE FUNCTION IN ELDERLY INDIVIDUALS: A META-ANALYSIS
}

\author{
Tomader Taha Abdel Rahman ${ }^{1}$, Mohamed Shawky Khater ${ }^{1}$, Mohamad Farouk Allam ${ }^{2}$ \\ 1 Geriatric Medicine \& Gerontology department, Faculty of Medicine, Ain Shams University, Cairo, Egypt. \\ 2 Department of Community, Environmental and Occupational Medicine, Faculty of Medicine, Ain Shams University.
}

\begin{abstract}
Background: Sarcopenia (the loss of muscle mass and strength) has estimated prevalence rates of 5-13\% and 11$50 \%$ in the young-old and old-old, respectively. Recent studies have shown that vitamin D plays important roles in various systems, including the musculoskeletal system. Objective:
\end{abstract}

The aim of this meta-analysis was to determine the effects of vitamin $D$ supplementation on muscle function in community-dwelling elderly individuals.

Methods: We conducted systematic searches of PubMed, Medline, Egyptian Knowledge Bank, and the reference sections of previous reviews, and we discussed the topic with several experts in the field. Only randomized controlled trials that evaluated the effect of vitamin $D$ supplementation on muscle function [muscle strength was evaluated by the hand grip strength (HGS) test, and physical performance was evaluated by the timed up-and-go (TUG) test] were included. Only studies published in English between January 2000 and June 2018 were considered.

Results: In total, 14 randomized controlled clinical trials (RCTs) met our inclusion criteria. The participants in these studies were all community-dwelling elderly individuals, who were generally in good health for their age. The pooled mean difference in HGS was higher in the vitamin D supplementation group than in the control group. The pooled mean difference in the TUG test was slightly lower in the vitamin D supplementation group than in the control group.

Conclusions: Our meta-analysis shows that vitamin D supplementation could improve muscle function in elderly individuals. Future studies should use standardized durations and doses of vitamin D supplementation.

Keywords: Vitamin D supplementation, Sarcopenia, Muscle function, Meta-analysis, Randomized controlled clinical trials, Systematic review.

\section{Background}

The changes in body composition and functions that occur in the ageing population include decreases in skeletal muscle mass, strength, and mobility. These decreases in muscle mass and strength are collectively called sarcopenia, which is associated with frailty and falls 1 .

The prevalence rates of sarcopenia are 5-13\% and 11$50 \%$ in young-old and old-old individuals, respectively. These prevalence rates illustrate that decreases in muscle mass and strength constitute an important problem among elderly individuals. Early intervention may be helpful for limiting sarcopenia and preserving muscle mass and strength ${ }^{2}$.

Elderly individuals are susceptible to developing vitamin D deficiency due to various risk factors, such as diminished sunlight exposure, decreased skin thickness, impaired intestinal absorption, and reduced hydroxylation in the liver and kidneys. Decreased dietary intake and limited dietary sources of vitamin D also play important roles in vitamin D deficiency among elderly individuals ${ }^{[3 .}$ The decrease in vitamin D receptors that occurs with increasing age partly explains the age-related decrease in muscle function ${ }^{4}$. These risk factors make vitamin D deficiency more 
among elderly individuals than among young adults, even without the presence of other overt nutrient deficiencies $\mathbf{5 , 6}$.

Many interventions, including dietary supplementation regimens, such as supplementation with protein and omega-3 fatty acids ${ }^{3,7}$, and exercise interventions ${ }^{8}$ or combinations of the two, have been tested ${ }^{9}$.

Supplementation with vitamin D is one possible intervention. Vitamin D supplementation has been promoted as having positive effects on older persons, particularly with regard to the risk of falls and fractures ${ }^{10}$.

An increased risk of falls is a consequence of low muscle strength and mass ${ }^{\mathbf{1 1}}$, and sarcopenia is a risk factor for fractures in elderly individuals ${ }^{\mathbf{1 2}}$.

Although many researchers have tried to test the effects of vitamin D supplementation on muscle function, the results remain controversial, and it is still hard to conclude whether vitamin D supplementation has an effect on muscle strength in elderly individuals ${ }^{6}$.

The aim of our meta-analysis was to investigate the effects of vitamin D supplementation (with or without calcium) on muscle function among community-dwelling elderly individuals based on the results from randomized controlled clinical trials (RCTs).

Methods

\section{Literature Review}

Published RCTs on sarcopenia and vitamin D supplementation were identified through a comprehensive PubMed and Medline search (from January 2000 to June 2018) using a variety of keywords and subject headings related to sarcopenia, vitamin D supplementation, muscle strength and elderly individuals. We conducted additional searches of Egyptian Knowledge Bank and the cited references of previously published reviews, and we discussed the topic with several experts in the field. Published descriptive and analytical observational studies dealing with sarcopenia and vitamin D were excluded. We did not attempt to locate any unpublished studies.

Only RCTs with elderly community-dwelling individuals $>60$ years of age were included. We applied no restrictions with regard to the dose, forms and duration of vitamin D supplementation or the duration of follow-up; we included studies regardless of their use of calcium supplements and dietary advice. Measures of muscle function included the determination of muscle strength by the hand grip strength (HGS) test and the measurement of physical performance by the timed up-and-go test (TUG). These measures were compared before and after intervention for both groups (vitamin D supplementation versus placebo).

\section{Data Extraction}

Only 14 RCTs out of 2408 studies met the inclusion criteria and were included in this meta-analysis. A copy of each RCT was obtained, and relevant data were abstracted by the first author (T.T.A.) for a quantitative overview. In case of discrepancies or when the information presented in a study was unclear, the data was extracted by a second reviewer (M.F.A.) to resolve the discrepancy.

\section{Statistical Methods for Meta-Analysis}

Mean differences between cases and controls groups were calculated by subtracting the mean of the outcome of each result in each paper at the end of the study from the mean at the baseline or the start of the same study; Microsoft Excel 2010 was used for these calculations.

The pooled mean differences were obtained by weighing each study by the inverse variance of the effect measure on a logarithmic scale. This approach to pooling the results assumes that the study populations being compared were similar and hence corresponds to a fixed effect analysis. The validity of pooling the mean differences was tested (test of homogeneity) using the chi-square test.

A violation of this test suggests that the studies being pooled differ from one another. In the presence of significant heterogeneity of the effect measure among studies being compared, we performed a random effect analysis that was based on the method described by Der Simonian and Laird. The random effect analysis accounts for inter-study variation. Because the test of homogeneity has low power, we reported the figures of the random effect analysis even in the absence of significant heterogeneity.

All statistical analyses pertaining to the 14 pooled RCTs were performed with STATA version 14.0 (Stata Corp. 2015, College Station, Texas, USA).

\section{RESULTS}

We included 14 RCTs, with a total of 2127 participants aged 60 years and older. The average age of the included participants was 68.8 years (ranging from 60 to 88 years). The ratio of women to men was approximately 3.25:1 (1627/500).

All selected studies reported randomization in their design. The participants were all community-dwelling elderly individuals who were generally in good agerelated health. All studies excluded patients with acute illnesses.

Vitamin D was measured as the $25(\mathrm{OH}) \mathrm{D}$ concentration in all included RCTs using chromatographic methods, radioimmunoassays (DiaSorin Inc., Stillwater, $\mathrm{MN}$, USA), the IDS gamma-B 25-OH immunoassay (IDS, Tyne \& Wear, UK), and the Liaison method (DiaSorin Inc.). One RCT study did not report which method had been used. The mean baseline concentration of vitamin $\mathrm{D}$ ranged from 11 to $55 \mathrm{nmol} / \mathrm{L}$.

One RCT used different supplementation dosages, and another RCT used different durations of follow-up, and we considered each one as two clinical trials.

Vitamin D3 supplementation was administered orally at various doses (ranged from 400 - 3333 IU) and for different treatment periods (ranged from 3-24 months) 
Season was an important covariate as a result of internal vitamin $\mathrm{D}$ production due to exposure to ultraviolet-B radiation. The seasons during which the clinical trials were conducted were not documented in all studies.

Seven of the fourteen included RCTs added calcium supplements to the vitamin D supplements. The dose of calcium supplementation ranged from 500 to $1000 \mathrm{mg}$. Two studies evaluated the overall nutrient intake in addition to supplementation.

Other variables, such as body mass index, ethnicity and smoking, were usually not considered.

The dropout rate was reported in 2 RCTs as $10 \%$ and $22 \%$. In one RCT, the authors noted that the dropout rate was low without providing more details; in 11 $\mathrm{RCTs}$, the dropout rate was not reported at all.
Compliance was not reported in 3 of the 14 RCTs. In 8 RCTs, the compliance was reported to be good. In 2 RCTs, the compliance rate was $100 \%$ for the participants completing the study. In one RCT, it was stated that a daily compliance calendar had been used but the results were not reported. One RCT did not mention whether it had been blinded. We found an improvement in mobility and muscle function in 10 RCTs.

\section{Study outcomes}

The pooled mean difference in HGS was higher in the vitamin D supplementation group than in the control group. The pooled mean difference in the TUG test was slightly lower in the vitamin D supplementation group than in the control group. The meta-analysis shows that vitamin D supplementation could improve muscle function in elderly people.

Table (1): The mean values of hand grip strength among the studied RCTs.

\begin{tabular}{|c|c|c|c|c|c|c|}
\hline Authors & $\begin{array}{ll}\text { Hand } & \text { grip } \\
\text { baseline } & \\
\text { (vitamind } & \\
\text { group) } & \end{array}$ & $\begin{array}{l}\text { Hand grip after } \\
\text { supplementatio } \\
\text { n (vitamin D } \\
\text { group) }\end{array}$ & $\begin{array}{l}\text { Mean } \\
\text { difference } \\
\text { (vitaminD } \\
\text { group) }\end{array}$ & $\begin{array}{l}\text { Hand grip } \\
\text { baseline } \\
\text { (control group) }\end{array}$ & $\begin{array}{l}\text { Hand grip after } \\
\text { supplementatio } \\
\text { n } \quad \text { (control } \\
\text { group) }\end{array}$ & $\begin{array}{l}\text { Mean } \\
\text { difference } \\
\text { (control } \\
\text { group) }\end{array}$ \\
\hline $\begin{array}{l}\text { Anne et al., } \\
2003\end{array}$ & $36.1 \pm 6.7$ & $37.6 \pm 7.9$ & 1.50 & $32.9 \pm 9.1$ & $34.7 \pm 8.0$ & 1.80 \\
\hline $\begin{array}{l}\text { Behnaz et al., } \\
2016\end{array}$ & $24.5 \pm 10.64$ & $24.6 \pm 4.84$ & 0.10 & $24.05 \pm 5.86$ & $23.02 \pm 6.18$ & -1.03 \\
\hline $\begin{array}{l}\text { Mirjam et al., } \\
2014\end{array}$ & $32 \pm 3$ & $31 \pm 3.1$ & -1.00 & $33 \pm 2.3$ & $35 \pm 4.8$ & 2.00 \\
\hline $\begin{array}{l}\text { Verhaar et al., } \\
2000\end{array}$ & $20.3 \pm 2.5$ & $21.7 \pm 2.6$ & 1.40 & $22.6 \pm 1.5$ & $23.0 \pm 1.3$ & 0.40 \\
\hline $\begin{array}{l}\text { Bischoff et al., } \\
2003\end{array}$ & $20.5 \pm 1.3$ & $22.3 \pm 3.2$ & 1.80 & $19.0 \pm 1.5$ & $19.0 \pm 1.5$ & 0.00 \\
\hline $\begin{array}{l}\text { Pfeifer et al., } \\
2009\end{array}$ & $21.1 \pm 8.3$ & $23.6 \pm 7.5$ & 1.25 & $21.7 \pm 9.0$ & $22.4 \pm 8.3$ & 0.35 \\
\hline $\begin{array}{l}\text { Pfeifer et al., } \\
2009\end{array}$ & $21.1 \pm 8.3$ & $22.9 \pm 8.3$ & 1.80 & $21.7 \pm 9.0$ & $21.3 \pm 9.2$ & -0.40 \\
\hline $\begin{array}{l}\text { Verschueren et } \\
\text { al., } 2011\end{array}$ & $24.48 \pm 2.5$ & $29.6 \pm 2.5$ & 5.12 & $27.98 \pm 4.6$ & $29.0 \pm 4.7$ & 1.02 \\
\hline $\begin{array}{l}\text { Verschueren et } \\
\text { al., } 2011\end{array}$ & $28.4 \pm 2.8$ & $23.34 \pm 3.5$ & 2.47 & $25.2 \pm 6.3$ & $26.19 \pm 5.5$ & 0.5 \\
\hline $\begin{array}{l}\text { Roseane et al., } \\
2015\end{array}$ & $17.4 \pm 2.68$ & $19.9 \pm 3.53$ & 2.50 & $16.87 \pm 3.99$ & $17.93 \pm 4.91$ & 1.06 \\
\hline $\begin{array}{l}\text { Hansen et al., } \\
2015\end{array}$ & $18.8 \pm 2.5$ & $19.86 \pm 2.5$ & 0.53 & $19.77 \pm 3.02$ & $20.32 \pm 2.88$ & 0.28 \\
\hline $\begin{array}{l}\text { Hansen et al., } \\
2015\end{array}$ & $18.78 \pm 2.09$ & $19.83 \pm 2.27$ & 1.05 & $19.77 \pm 3.02$ & $20.32 \pm 2.88$ & 0.55 \\
\hline $\begin{array}{l}\text { Kirsti et al., } \\
2015\end{array}$ & $23.4 \pm 7.7$ & $23.6 \pm 6.6$ & 0.20 & $23.1 \pm 6.1$ & $22.2 \pm 6.0$ & -0.90 \\
\hline $\begin{array}{l}\text { Mariangela et } \\
\text { al., } 2016\end{array}$ & $16.63 \pm 4.99$ & $19.83 \pm 2.27$ & 3.20 & $19.62 \pm 6.01$ & $20.32 \pm 2.88$ & 0.70 \\
\hline $\begin{array}{l}\text { Sonja et al., } \\
2009\end{array}$ & $24.2 \pm 7.4$ & $24.4 \pm 7.5$ & 0.20 & $21.2 \pm 7.5$ & $21.1 \pm 7.7$ & -0.10 \\
\hline $\begin{array}{l}\text { Sonja et al., } \\
2009\end{array}$ & $24.2 \pm 7.4$ & $25.2 \pm 7.6$ & 0.5 & $21.2 \pm 7.5$ & $21.1 \pm 7.4$ & -0.05 \\
\hline $\begin{array}{l}\text { Kana et al., } \\
2018\end{array}$ & $33.3 \pm 6.35$ & $34.0 \pm 5.92$ & 0.70 & $31.3 \pm 7.6$ & $33.1 \pm 6.04$ & 1.80 \\
\hline $\begin{array}{l}\text { Cangusus1 et } \\
\text { al., 2015 }\end{array}$ & $23.8 \pm 12.3$ & $24.4 \pm 13.4$ & 0.60 & $24.2 \pm 10.5$ & $23.9 \pm 10.7$ & -0.30 \\
\hline
\end{tabular}


Table 2: The mean values of the timed up-and-go test among the studied RCTs

\begin{tabular}{|c|c|c|c|c|c|c|c|}
\hline Authors & $\begin{array}{l}\text { Timed up-and- } \\
\text { go } \\
\text { baseline } \\
\text { (vitamin } \\
\text { group) }\end{array}$ & $\begin{array}{l}\text { Timed up-and- } \\
\text { go test after } \\
\text { supplementati } \\
\text { on (vitamin D } \\
\text { group) }\end{array}$ & $\begin{array}{l}\text { Mean } \\
\text { difference } \\
\text { (vitamin } \\
\text { group) }\end{array}$ & D & $\begin{array}{l}\text { Timed up-and- } \\
\text { go } \\
\text { baseline } \\
\text { (control } \\
\text { group) }\end{array}$ & $\begin{array}{l}\text { Timed up-and- } \\
\text { go test after } \\
\text { supplementati } \\
\text { on (control } \\
\text { group) }\end{array}$ & $\begin{array}{l}\text { Mean } \\
\text { difference } \\
\text { (control } \\
\text { group) }\end{array}$ \\
\hline $\begin{array}{l}\text { Anne et al., } \\
2003\end{array}$ & $10.5 \pm 2.5$ & $10.9 \pm 2.6$ & -0.40 & & $10.6 \pm 4.5$ & $11.3 \pm 5.7$ & -0.70 \\
\hline $\begin{array}{l}\text { Behnaz et al } \\
2016\end{array}$ & $9.75 \pm 2.07$ & $8.27 \pm 1.74$ & 1.48 & & $10.05 \pm 1.79$ & $10.29 \pm 2.03$ & -0.24 \\
\hline $\begin{array}{l}\text { Mirjam et al, } \\
2014\end{array}$ & $10.7 \pm 2.3$ & $10.9 \pm 2.3$ & -0.20 & & $10.5 \pm 4.8$ & $10.9 \pm 5.7$ & -0.40 \\
\hline $\begin{array}{l}\text { Verhaar et } \\
\text { al., } 2000\end{array}$ & $13.2 \pm 4.7$ & $8.4 \pm 4.7$ & 4.80 & & $4.6 \pm 0.22$ & $5.0 \pm 0.25$ & -0.40 \\
\hline $\begin{array}{l}\text { Bischoff et } \\
\text { al., } 2003\end{array}$ & $15.0 \pm 9.5$ & $15.0 \pm 9.5$ & 0.00 & & $13.0 \pm 7.0$ & $10.0 \pm 5.0$ & 3.00 \\
\hline $\begin{array}{l}\text { Pfeifer et al., } \\
2009\end{array}$ & $9.0 \pm 5.9$ & $7.5 \pm 3.4$ & 0.75 & & $8.5 \pm 3.9$ & $8.3 \pm 5.1$ & 0.1 \\
\hline $\begin{array}{l}\text { Pfeifer et al., } \\
2009\end{array}$ & $9.0 \pm 5.9$ & $7.3 \pm 3.4$ & 1.70 & & $8.5 \pm 3.9$ & $8.2 \pm 4.8$ & 0.30 \\
\hline $\begin{array}{l}\text { Verschueren } \\
\text { et al } 2011\end{array}$ & $10.5 \pm 2.5$ & $10.9 \pm 2.6$ & -0.40 & & $10.6 \pm 4.5$ & $11.3 \pm 5.7$ & -0.70 \\
\hline $\begin{array}{l}\text { Verschueren } \\
\text { et al., } 2011\end{array}$ & $9.75 \pm 2.07$ & $8.27 \pm 1.74$ & 0.74 & & $10.05 \pm 1.79$ & $10.29 \pm 2.03$ & -0.12 \\
\hline $\begin{array}{l}\text { Roseane et } \\
\text { al., } 2015\end{array}$ & $9.75 \pm 2.07$ & $8.27 \pm 1.74$ & 1.48 & & $10.05 \pm 1.79$ & $10.29 \pm 2.03$ & -0.24 \\
\hline $\begin{array}{l}\text { Hansen et al., } \\
2015\end{array}$ & $8.04 \pm 1.56$ & $7.6 \pm 1.59$ & 0.22 & & $8.28 \pm 1.69$ & $7.92 \pm 1.59$ & 0.18 \\
\hline $\begin{array}{l}\text { Hansen et al., } \\
2015\end{array}$ & $8.03 \pm 1.7$ & $7.65 \pm 1.77$ & 0.38 & & $8.28 \pm 1.69$ & $7.92 \pm 1.59$ & 0.36 \\
\hline $\begin{array}{l}\text { Kirsti et al., } \\
2015\end{array}$ & $12.6 \pm 3.3$ & $9.3 \pm 2.1$ & 3.30 & & $12.0 \pm 2.4$ & $9.7 \pm 6.4$ & 2.30 \\
\hline $\begin{array}{l}\text { Mariangela et } \\
\text { al., } 2016\end{array}$ & $9.0 \pm 5.9$ & $7.5 \pm 3.4$ & 1.50 & & $8.5 \pm 3.9$ & $8.3 \pm 5.1$ & 0.20 \\
\hline $\begin{array}{l}\text { Sonja et al., } \\
2009\end{array}$ & $9.9 \pm 2.9$ & $13 \pm 6$ & -3.10 & & $10.3 \pm 2.8$ & $10 \pm 7$ & 0.30 \\
\hline $\begin{array}{l}\text { Sonja et al., } \\
2009\end{array}$ & $9.9 \pm 2.9$ & $13 \pm 7$ & -1.55 & & $10.3 \pm 2.8$ & $15 \pm 6$ & -2.35 \\
\hline $\begin{array}{l}\text { Kana et al., } \\
2018\end{array}$ & $10.6 \pm 11.2$ & $9.65 \pm 13.8$ & 0.95 & & $9.76 \pm 11.3$ & $8.62 \pm 9.6$ & 1.14 \\
\hline $\begin{array}{l}\text { Cangusus1 et } \\
\text { al., } 2015\end{array}$ & $12.6 \pm 6.6$ & $15.8 \pm 4.6$ & -3.20 & & $13.3 \pm 6.2$ & $13.1 \pm 5.4$ & 0.20 \\
\hline
\end{tabular}

Table 3: Effect of vitamin D supplementation on hand grip strength

\begin{tabular}{lllllll}
\hline Study & N1 & N2 & Total & SMD & SE & 95\% CI \\
& & & & & & \\
Anne et al., 2003 & 32 & 32 & 64 & 0.360 & 0.249 & -0.137 to 0.858 \\
\hline Behnaz et al 2016 & 37 & 34 & 71 & 0.283 & 0.236 & -0.188 to 0.754 \\
Mirjam et al, 2014 & 65 & 65 & 130 & -0.984 & 0.185 & -1.350 to -0.619 \\
\hline Verhaar et al., 2000 & 27 & 13 & 40 & -0.561 & 0.337 & -1.243 to 0.121 \\
Bischoff et al., 2003 & 62 & 60 & 122 & 1.305 & 0.198 & 0.912 to 1.698 \\
\hline Pfeifer et al., 2009 & 121 & 121 & 242 & 0.151 & 0.128 & -0.102 to 0.404 \\
Pfeifer et al., 2009 & 121 & 121 & 242 & 0.182 & 0.128 & -0.0709 to 0.435 \\
\hline
\end{tabular}


Table 3(continued):

\begin{tabular}{lllllll}
\hline Study & N1 & N2 & Total & SMD & SE & 95\% CI \\
\hline Verschueren et al 2011 & 26 & 29 & 55 & 0.155 & 0.267 & -0.380 to 0.690 \\
\hline Verschueren et al., 2011 & 28 & 28 & 56 & -0.610 & 0.270 & -1.150 to -0.0688 \\
Roseane et al., 2015 & 19 & 19 & 38 & 0.451 & 0.322 & -0.202 to 1.104 \\
\hline Hansen et al., 2015 & 75 & 76 & 151 & -0.170 & 0.162 & -0.490 to 0.151 \\
\hline Hansen et al., 2015 & 79 & 76 & 155 & -0.188 & 0.160 & -0.505 to 0.128 \\
Kirsti et al., 2015 & 102 & 102 & 204 & 0.221 & 0.140 & -0.0548 to 0.497 \\
Mariangela et al., 2016 & 69 & 61 & 130 & -0.189 & 0.175 & -0.536 to 0.157 \\
Sonja et al., 2009 & 45 & 44 & 89 & 0.430 & 0.213 & 0.00783 to 0.853 \\
Sonja et al., 2009 & 45 & 44 & 89 & 0.542 & 0.214 & 0.116 to 0.967 \\
\hline Kana et al., 2018 & 43 & 44 & 87 & 0.149 & 0.213 & -0.274 to 0.572 \\
Cangusus1 et al., 2015 & 80 & 80 & 160 & 0.0410 & 0.157 & -0.270 to 0.352 \\
Pooling Fixed effects & 1076 & 1049 & 2125 & 0.0884 & 0.0437 & 0.00267 to 0.174 \\
Pooling Random effects & 1076 & 1049 & 2125 & 0.0905 & 0.110 & -0.126 to 0.307 \\
\hline
\end{tabular}

Table 4: Test for heterogeneity of HGS

\begin{tabular}{ll}
\hline $\mathbf{Q}$ & $\mathbf{1 0 1 . 8 8 2 7}$ \\
\hline DF & 17 \\
Significance level & $\mathrm{P}<0.0001$ \\
$\mathbf{I}^{2}$ (inconsistency) & $83.31 \%$ \\
$\mathbf{9 5 \%}$ CI for $\mathbf{I}^{\mathbf{2}}$ & 74.82 to 88.94 \\
\hline
\end{tabular}

Figure 1 Standardized mean differences in hand grip strength

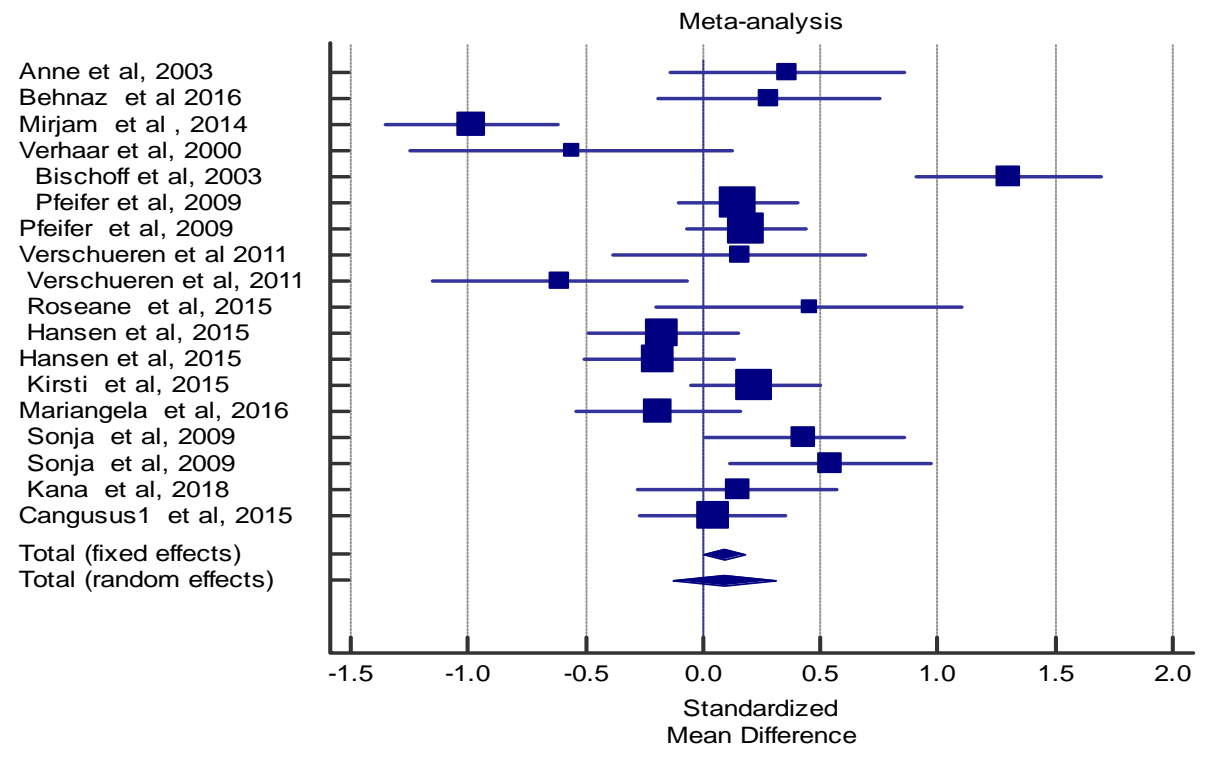


Table 5: Effect of vitamin D supplementation on the timed up-and-go test

\begin{tabular}{|c|c|c|c|c|c|c|}
\hline Study & N1 & $\mathbf{N 2}$ & Total & SMD & SE & $95 \% \mathrm{CI}$ \\
\hline Anne et al., 2003 & 32 & 32 & 64 & -0.169 & 0.247 & -0.664 to 0.325 \\
\hline Behnaz et al 2016 & 37 & 34 & 71 & -0.483 & 0.238 & -0.959 to -0.00721 \\
\hline Mirjam et al, 2014 & 65 & 65 & 130 & 0.000 & 0.174 & -0.345 to 0.345 \\
\hline Verhaar et al., 2000 & 27 & 13 & 40 & 0.695 & 0.340 & 0.00670 to 1.383 \\
\hline Bischoff et al., 2003 & 62 & 60 & 122 & 0.649 & 0.185 & 0.283 to 1.014 \\
\hline Pfeifer et al., 2009 & 121 & 121 & 242 & -0.192 & 0.128 & -0.445 to 0.0613 \\
\hline Pfeifer et al., 2009 & 121 & 121 & 242 & -0.191 & 0.128 & -0.444 to 0.0619 \\
\hline Verschueren et al 2011 & 26 & 29 & 55 & -0.170 & 0.267 & -0.705 to 0.365 \\
\hline Verschueren et al., 2011 & 28 & 28 & 56 & -1.054 & 0.282 & -1.618 to -0.489 \\
\hline Roseane et al., 2015 & 19 & 19 & 38 & -1.046 & 0.340 & -1.735 to -0.357 \\
\hline Hansen et al., 2015 & 75 & 76 & 151 & -0.200 & 0.162 & -0.521 to 0.121 \\
\hline Hansen et al., 2015 & 79 & 76 & 155 & -0.160 & 0.160 & -0.476 to 0.157 \\
\hline Kirsti et al., 2015 & 102 & 102 & 204 & -0.0837 & 0.140 & -0.359 to 0.192 \\
\hline Mariangela et al., 2016 & 69 & 61 & 130 & -0.186 & 0.175 & -0.532 to 0.161 \\
\hline Sonja et al., 2009 & 45 & 44 & 89 & 0.457 & 0.213 & 0.0333 to 0.880 \\
\hline Sonja et al., 2009 & 45 & 44 & 89 & -0.304 & 0.211 & -0.724 to 0.116 \\
\hline Kana et al., 2018 & 43 & 44 & 87 & 0.0861 & 0.213 & -0.337 to 0.509 \\
\hline Cangusus1 et al., 2015 & 80 & 80 & 160 & 0.536 & 0.160 & 0.219 to 0.852 \\
\hline Pooled fixed effects & 1076 & 1049 & 2125 & -0.0612 & 0.0435 & -0.147 to 0.0242 \\
\hline Pooled random effects & 1076 & 1049 & 2125 & -0.0814 & 0.0913 & -0.260 to 0.0977 \\
\hline
\end{tabular}

Table 6: Test for heterogeneity of the timed up-and-go test

\begin{tabular}{ll}
\hline $\mathbf{Q}$ & $\mathbf{1 0 9 . 4 4 7 1}$ \\
\hline DF & 18 \\
Significance level & $\mathrm{P}<0.0001$ \\
$\mathbf{I}^{2}$ (inconsistency) & $75.52 \%$ \\
${\text { 95\% CI for } \mathbf{I}^{2}}^{\mathbf{9 5}}$ & 71.35 to 84.49 \\
\hline
\end{tabular}

Figure 2 Standardized mean differences in the times up-and-go test

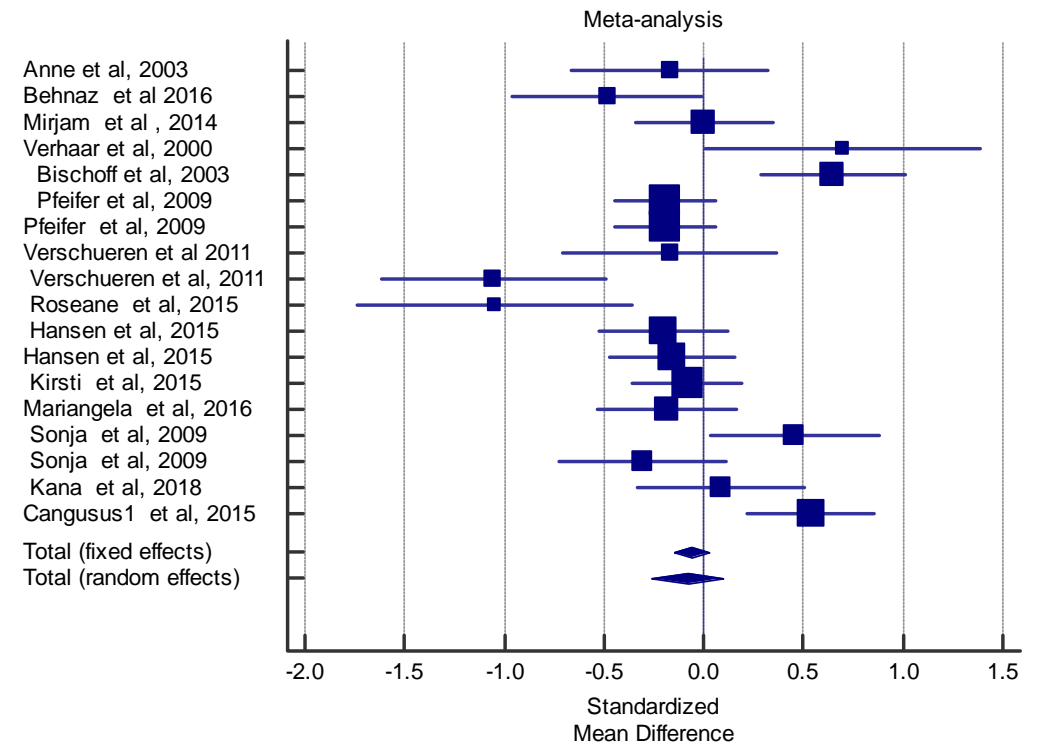




\section{DISCUSSION}

The geriatric population is a heterogeneous age group. Individuals in this group differ in terms of age, place of living, social status, existence of chronic illnesses, and quality of life. Therefore, it is predicted that studies among the geriatric population will, in general, present mixed results unless the population is defined more precisely according to the factors mentioned previously. Therefore, we limited the present metaanalysis to community-dwelling apparently healthy elderly individuals. It is known that communitydwelling elderly populations are usually healthier than those who are hospitalized or institutionalized. Community-dwelling individuals were targeted to limit the heterogeneity among the geriatric population.

The outcomes of this study were determined by the results of the HGS and the TUG tests, which are the only quantifiable outcomes that have been used as measurements of the decline in muscle strength and muscle function ${ }^{\mathbf{}}$.

The aim of this meta-analysis was to investigate whether vitamin D supplementation (with or without calcium) in community-dwelling elderly individuals contributes to improved muscle function. Based on the findings of this meta-analysis, we conclude that vitamin D supplementation has a significant effect on muscle function, (HGS, p=0.043; TUG, p=0.049). This can be explained by the effect of vitamin D on type 2 muscle fibres ${ }^{13}$. In addition to the effects of vitamin $\mathrm{D}$ on neuromuscular control and neural coordination, there is growing evidence supporting a neurotrophic effect of vitamin $\mathrm{D}^{\mathbf{1 4}}$

\section{Strengths and limitations}

The strength of this meta-analysis was the usage of data from 14 RCTs, with approximately 2127 participants. The HGS and TUG tests are the only quantifiable outcomes that have been used as measurements of the decline in muscle strength and muscle function.

The limitations of this study are the discrepancies between RCTs in terms of the doses of vitamin D, type of supplement, duration of supplementation, and participants' baseline vitamin D status, which made comparisons between studies difficult.

\section{CONCLUSION}

Our meta-analysis shows that vitamin D supplementation could improve muscle function in elderly individuals. Future studies should use standardized durations and doses of vitamin D supplementation.

\section{References}

1- [1] Cruz-Jentoft AJ, Baeyens JP, Bauer JM (2010). Sarcopenia: European consensus on definition and diagnosis: report of the European Working Group on Sarcopenia in Older People. Age Ageing 39, 412-23.
2- [2] Morley JE (2012). Sarcopenia in the elderly. Fam Pract 29(Suppl 1), i44-i48.

3- [3] Malafarina V, Uriz-Otano F, Iniesta R, et al. (2013). Effectiveness of nutritional supplementation on muscle mass in treatment of sarcopenia in old age: a systematic review. J Am Med Dir Assoc 14, 10-7.

4- [4] Bischoff-Ferrari HA, Borchers M, Gudat F, et al. (2004). Vitamin $D$ receptor expression in human muscle tissue decreases with age. J Bone Miner Res 19, 265-9.

5- [5] Brouwer-Brolsma EM, Bischoff-Ferrari HA, Bouillon R, et al. (2013). Vitamin D: do we get enough? A discussion between vitamin $D$ experts in order to make a step towards the harmonisation of dietary reference intakes for vitamin $D$ across Europe. Osteoporos Int 24, 1567-77.

6- [6] Avenell A, Mak Jenson CS and O'Connell D (2014). Vitamin D and vitamin $D$ analogues for preventing fractures in post-menopausal women and older men

7- [7] Aleman-Mateo H, Macias L, Esparza-Romero J, et al. (2012). Physiological effects beyond the significant gain in muscle mass in sarcopenic elderly men: evidence from a randomized clinical trial using a protein-rich food. Clin Interv Aging 7, 225-34.

8- [8] Liu CK, Leng X, Hsu FC, et al. (2014). The impact of sarcopenia on a physical activity intervention: the Lifestyle Interventions and Independence for Elders Pilot Study (LIFE-P). J Nutr Health Aging 18, 59-64.

9- [9] Hara S, Kishimoto KN, Okuno H, et al. (2013). Effects of alfacalcidol on back extensor strength gained through back extensor exercise in postmenopausal women with osteoporosis. Am J Phys Med Rehabil 92, 101-10.

10- [10] Murad MH, Elamin KB, Abu Elnour NO, et al. (2011). Clinical review: the effect of vitamin $D$ on falls: a systematic review and meta-analysis. J Clin Endocrinol Metab 96, 2997-3006.

11- [11] Kojima G (2015). Frailty as a predictor of future falls among community-dwelling older people: a systematic review and meta-analysis. J Am Med Dir Assoc 16, 1027-33.

12- [12] Deandrea S, Lucenteforte E, Bravi F, et al. (2010). Risk factors for falls in community-dwelling older people: a systematic review and meta-analysis. Epidemiology 21, 658-68.

13- [13] Ceglia L., Harris S. S. (2013). Vitamin D and its role in skeletal muscle. Calcified Tissue International;92(2):151-162.

14- [14] Annweiler C, Schott AM, Berrut G et al. (2010). Vitamin D and ageing: Neurological issues. Neuropsychobiology ;62:139150.Somwaru LL, Rariy CM, Arnold AM, Cappola AR: The natural history of subclinical hypothyroidism in the elderly: the cardiovascular health study. J Clin Endocrinol Metab 2012, 97:1962-1969. 


\section{Appendix 1}

\begin{tabular}{|c|c|c|c|c|c|}
\hline Authors & Number of participants & Male & Male & Female & Female \\
\hline & & cases & controls & cases & controls \\
\hline Anne et al., 2003 & 65 & 33 & 32 & 0 & 0 \\
\hline Behnaz et al 2016 & 71 & 0 & 0 & 37 & 34 \\
\hline Mirjam et al, 2014 & 130 & 40 & 40 & 25 & 25 \\
\hline Verhaar et al., 2000 & 40 & 0 & 0 & 27 & 13 \\
\hline Bischoff et al., 2003 & 122 & 0 & 0 & 62 & 60 \\
\hline Pfeifer et al., 2009 & 242 & 26 & 25 & 95 & 96 \\
\hline Pfeifer et al., 2009 & 242 & 26 & 25 & 95 & 96 \\
\hline Verschueren et al 2011 & 55 & 0 & 0 & 26 & 29 \\
\hline Verschueren et al., 2011 & 56 & 0 & 0 & 28 & 28 \\
\hline Roseane et al., 2015 & 38 & 0 & 0 & 19 & 19 \\
\hline Hansen et al., 2015 & 151 & 0 & 0 & 75 & 76 \\
\hline Hansen et al., 2015 & 155 & 0 & 0 & 79 & 76 \\
\hline Kirsti et al., 2015 & 204 & 0 & 0 & 102 & 102 \\
\hline Mariangela et al., 2016 & 130 & 29 & 24 & 40 & 37 \\
\hline Sonja et al., 2009 & 89 & 45 & 44 & 0 & 0 \\
\hline Sonja et al., 2009 & 89 & 45 & 44 & 0 & 0 \\
\hline Kana et al., 2018 & 88 & 11 & 10 & 32 & 34 \\
\hline Cangusus1 et al., 2015 & 160 & 0 & 0 & 80 & 80 \\
\hline
\end{tabular}

Appendix 2:

\begin{tabular}{lcc}
\hline Authors & Mean age of cases & Mean age of controls \\
\hline Anne et al, 2003 & $77.0 \pm 4.0$ & $76.0 \pm 5.0$ \\
Behnaz et al 2016 & $45.2 \pm 2.6$ & $45.7 \pm 3.1$ \\
Mirjam et al, 2014 & $48.9 \pm 10.3$ & $51.5 \pm 10.5$ \\
Verhaar et al., 2000 & $75 \pm 3.2$ & $76.5 \pm 1.4$ \\
Bischoff et al., 2003 & $84.9 \pm 7.7$ & $85.4 \pm 5.9$ \\
Pfeifer et al., 2009 & $76.0 \pm 4.0$ & $77.0 \pm 4.0$ \\
Pfeifer et al., 2009 & $76.0 \pm 4.0$ & $77.0 \pm 4.0$ \\
Verschueren et al 2011 & $80.3 \pm 5.3$ & $78.7 \pm 5.6$ \\
Verschueren et al., 2011 & $79.8 \pm 5.3$ & $79.6 \pm 5.2$ \\
Roseane et al., 2015 & $62.2 \pm 7.6$ & $62.3 \pm 8$ \\
Hansen et al., 2015 & $60.0 \pm 6$ & $61 \pm 6$ \\
Hansen et al., 2015 & $60.0 \pm 5$ & $61 \pm 6$ \\
Kirsti et al., 2015 & $74.1 \pm 3.0$ & $73.8 \pm 3.1$ \\
Mariangela et al., 2016 & $80.77 \pm 6.29$ & $80.21 \pm 8.54$ \\
Sonja et al., 2009 & $61.7 \pm 7.7$ & $59.9 \pm 7.4$ \\
Sonja et al., 2009 & $61.7 \pm 7.7$ & $59.9 \pm 7.4$ \\
Kana et al., 2018 & $68.8 \pm 5.3$ & $71.2 \pm 6.8$ \\
Cangusus1 et al., 2015 & $58.8 \pm 6.6$ & $59.3 \pm 6.7$ \\
\hline
\end{tabular}


Appendix 3:

\begin{tabular}{|c|c|c|c|c|}
\hline Authors & $\begin{array}{c}\text { Vitamin D } \\
\text { supplementation } \\
\text { (dose) }\end{array}$ & $\begin{array}{c}\text { Duration of } \\
\text { supplementation }\end{array}$ & $\begin{array}{l}\text { Daily or weekly } \\
\text { supplementation }\end{array}$ & $\begin{array}{r}\text { Cal } \\
\text { supplen }\end{array}$ \\
\hline Anne et al., 2003 & $1000 \mathrm{IU}$ & 6 months & Daily & 500 \\
\hline Behnaz et al 2016 & $1000 \mathrm{IU}$ & 3 months & Daily & \\
\hline Mirjam et al, 2014 & $1200 \mathrm{IU}$ & 4 months & Daily & 5 \\
\hline Verhaar et al., 2000 & $1000 \mathrm{IU}$ & 6 months & Daily & \\
\hline Bischoff et al., 2003 & $400 \mathrm{IU}$ & 3 months & Daily & 6 \\
\hline Pfeifer et al., 2009 & $800 \mathrm{IU}$ & 12 months & Daily & 5 \\
\hline Pfeifer et al., 2009 & $800 \mathrm{IU}$ & 20 months & Daily & 5 \\
\hline Verschueren et al 2011 & $1600 \mathrm{IU}$ & 6 months & Daily & 100 \\
\hline Verschueren et al., 2011 & $880 \mathrm{IU}$ & 6 months & Daily & 100 \\
\hline Roseane et al., 2015 & $942 \mathrm{IU}$ & 3 months & Daily & \\
\hline Hansen et al., 2015 & $800 \mathrm{IU}$ & 12 months & Daily & \\
\hline Hansen et al., 2015 & $3333 \mathrm{IU}$ & 12 months & Daily & \\
\hline Kirsti et al., 2015 & $800 \mathrm{IU}$ & 24 months & Daily & \\
\hline Mariangela et al., 2016 & $1000 \mathrm{IU}$ & 3 months & Daily & \\
\hline Sonja et al., 2009 & $800 \mathrm{IU}$ & 12 months & Daily & \\
\hline Sonja et al., 2009 & $800 \mathrm{IU}$ & 18 months & Daily & \\
\hline Kana et al., 2018 & $1000 \mathrm{IU}$ & 6 months & Daily & \\
\hline Cangusus1 et al., 2015 & $1000 \mathrm{IU}$ & 9 months & Daily & \\
\hline
\end{tabular}

